Rev. Bras. Saúde Prod. Anim., Salvador, v.16, n.2, p.420-429 abr./jun.., 2015 http://www.rbspa.ufba.br ISSN 15199940 http://dx.doi.org/10.1590/S1519-99402015000200016

\title{
Performance, growth and carcass characteristics of alternatives lineages of broiler chickens created with access to paddock
}

\author{
Desempenho, crescimento e características de carcaça de linhagens alternativas de \\ frangos de corte criados com acesso a piquete
}

TAVARES, Fernando Barbosa ${ }^{1 *}$; SANTOS, Maria do Socorro Vieira dos ${ }^{2}$; ARAÚJO, Claudio Vieira de ${ }^{3}$; COSTA, Heiciane Soares da ${ }^{1}$; LOUREIRO, João Paulo Borges ${ }^{1}$; LIMA, Elizanne de Moura ${ }^{1}$; LIMA, Kedson Raul de Souza ${ }^{1}$

\author{
${ }^{1}$ Universidade Federal Rural da Amazônia, Instituto da Saúde e Produção Animal, Belém, Pará, Brasil. \\ ${ }^{2}$ Universidade Federal do Cariri, Barbalha, Ceará, Brasil. \\ ${ }^{3}$ Universidade Federal do Mato Grosso, Sinop, Mato Grosso, Brasil. \\ *Endereço para correspondência: fernando.tavares@ufra.edu.br
}

\section{SUMMARY}

The aim of this study was to evaluate the performance of alternative lineages of broiler chickens created with access to paddock. Were used 312 one day broiler chickens, house data density of $6.4 \mathrm{birds} / \mathrm{m} 2$ in the internal area and $2 \mathrm{~m}^{2} /$ animal in the pasture area. The treatments consisted of each lineage used in the experiment: Redbro Cou Nu, Gris Barré Cou Nu, Master Gris Cou Plume and Gris Barré Cou Plume. The statistical design was completely randomized with four treatments and six repetitions. For study the growth, the Gompertz equation showed a better adjustment compared with others. The lineage Master Gris Cou Plume got the greatest asymptotic weight, absolute growth rate and lowest viability, higher average weight and weight gain when compared to lineage Gris Barré Cou Nu. Even with the differences in zoo technical performance among the lineages studied, not the significance of differences between means indicates there is a ratio of body weight after fasting and weight of the eviscerated carcass. Showed highercarcass weight, chest, thigh + drumstick, wing and backin the lineage Master Gris Cou Plume, compared to Gris Barré Cou Nu and Gris Barré Cou Plume. The lineages Redbro Cou Nu and Master Gris Cou Plume had similar performance, but the Redbro Cou $\mathrm{Nu}$, showed growth characteristics more suitable to alternative creations with access to paddock area.

Keywords: animal growth rate, french redneck chicken, poultry farming family

\section{RESUMO}

Objetivou-se com este estudo avaliar o desempenho de linhagens alternativas de frangos de corte, criados em sistema com acesso a piquete. Foram utilizados 312 pintos de corte de um dia de idade, alojados com uma densidade de 6,4 aves/m2 na área interna e $2 \mathrm{~m}^{2} /$ animal na área de pastejo. Os tratamentos adotados corresponderam a cada linhagem: Redbro Cou Nu, Gris Barré Cou Nu, Master Gris Cou Plumé e Gris Barré Cou Plumé. O delineamento estatístico adotado foi inteiramente casualizado, com quatro tratamentos e seis repetições. Para o estudo do crescimento a equação de Gompertz apresentou melhor ajuste, quando comparadas ás demais. A linhagem Master Gris Cou Plumé obteve maior peso assintótico, taxa de crescimento absoluto máximo e menor viabilidade, maiores valores de peso médio e ganho de peso, quando comparada à linhagem Gris Barré Cou Nu. Mesmo com as diferenças de desempenho zootécnico entre as linhagens estudadas, não a diferenças significativas entre médias de peso do corpo após o jejum e peso das carcaças evisceradas. Foram observados maiores pesos de carcaça, peito, coxa+sobrecoxa, dorso e asa para a linhagem Master Gris Cou Plumé, quando comparado a Gris Barré Cou Nu e Gris Barré Cou Plumé. As linhagens Redbro Cou Nu e Master Gris Cou Plumé apresentaram desempenho similar, no entanto a aves da linhagem Redbro Cou $\mathrm{Nu}$ demonstraram características de crescimento mais adequadas a criações alternativas, com acesso a área de piquete.

Palavras chave: avicultura familiar, frango caipira francês, taxa de crescimento animal 
Rev. Bras. Saúde Prod. Anim., Salvador, v.16, n.2, p.420-429 abr./jun.., 2015 http://www.rbspa.ufba.br

\section{INTRODUCTION}

The expansion of intensive system of production of broiler chickens, together with the increased number of birds per square meter, provides an optimization of production by area. In contrast, this system of total confinement creates an environment unfavorable to the welfare of the birds that can promote a fall in production indices (HEMISTTER FILHO, 2003).

The environment of the creation system has a direct influence on the condition of comfort and animal welfare. These factors have prompted a search for new products and production technologies that respect the conditions of welfare (NAZARETH et al., 2009). In this context have grown alternative farming systems, which can be defined asproductiontotallyextensive, free food, "free-range" or semi-intensive, Label Rouge and even organic production. Each of these provides unique constraints and specific production methods (NARINC et al., 2010). Especially in Brazil exist for a significant share of consumers who have a preference for consuming the denominated "Redneck Chicken or Colonial Chicken "(BRAZIL, 1999).

To achieve profitability in this segment of the poultry industry, research in genetics has been conducted with the aim of develop birds more adapted to improve the rates of productive alternatives creations (FARMER et al., 1997, LEWIS et al., 1997; BOELLING et al, 2003). Several companies have setup in Brazilian order to provide genetic material of slow growth. However, few studies have focused on the growth performance of these lineages, as well as the adaptation of these in different Brazilian biomes.
The scientific community has had little interest to the challenges and opportunities of family farming. The high flexibility to adapt to different production processes and the variety of sources of income become a fundamental element of family farming and agricultural modernization, particularly of certain agro-industrial chains (GOMES, 2004). The broiler production in the system that have access to paddocks is employed, mostly by family farmers due to low cost, and Amazon is certainly one of the regions where this activity is manifested more clearly. (GALVÃO et al., 2005). Because it is aimed at evaluating the performance different strains of broilers raised with access to the paddock.

\section{MATERIAL AND METHODS}

Were used 312 broiler chicks a day, unsexed, from a commercial incubatory, vaccinated against Marek's disease, Gumboro and Bouba Avian, housed at a density of $6.4 \mathrm{birds} / \mathrm{m}^{2}$ in the internal area and $2 \mathrm{~m}^{2}$ /animal grazing area, created in semi-intensive system. The statistical design was completely randomized with four treatments and six replications and the experimental unit covers 13birds, totaling 78birds for eachtreatment.

The standard treatment corresponded to each lineage: 1- Redbro Cou Nu (lineage with red feathers and naked neck); 2- Gris Barré Cou Nu (lineage with pigmented feathers of black and white and naked neck); 3-Master Gris Cou Plume (lineage with dominance of white feathers rarely alternating with black feathers and feather neck); and 4Gris Barré Couplume (lineage with pigmented feathers of black and white and feathered neck). 
The experimental aviary used, had $20 \mathrm{~m}$ of length and $10 \mathrm{~m}$ of wide, ceiling of $3.5 \mathrm{~m}$, covered with fiber cement shingle, consisting of 24 experimental units, each containing two parts, one internal and one external. The internal was composed of a tubular feeder, semiautomatic, with a capacity of 15 kilos, and a pressure type water cooler with a capacity of 5 liters. The external area was surrounded and had a diverse vegetation composition, predominantly Brachiaria brizantha and Brachiaria humidicola previously planted, chosen for their occurrence in abundance in the region.

Before the arrival of animals, installations and equipment were cleaned, removing, initially the organic matter, cleaningand application

ofcommercialdisinfectantquaternary

ammoniumcompound. After drying, the sawdust was distributed evenly with about five centimeters of tall. The equipments were distributed in the aviary. In the beginning of experimental phase the broiler chicken with one day old, were individually weighed and classified according to their weight. Later, the experimental plots were distributed to form homogeneous groups. The experimental units had an average of chickens weight was 38.43 grams \pm 1.8 grams. For heating the animals were installed in an experimental phase electric lamps of 120 watts with almost $30 \mathrm{~cm}$ of high, being connected in the first seven days, according to the temperature inside the shed and with the behavior of the animals.

From the first to the seventh day of age were administered through the water, a multivitamin supplement, in the dosage recommended in the package leaflet. At seven days of age the birds were vaccinated against Newcastle disease, Cepa La Sota, by water, as recommended by the agency health protection in the region.

The feedingof the animalswas performedad libitum, and the feed program divided in to two phases: the initial phase was 1 to 28 days, and the fattening phase of 28 to 84 days. At 21 days of age, the doors were opened access to pasture every day, from 8:00 to $16: 00$ hours. The formulations of these diets as well as the chemical composition calculated are shown in Table1. The diets were formulated based on ingredients such as corn, soybean meal, meat and bone meal, soybean oil, salt and limestone. The vitamin and mineral supplement was used to broiler chicken, according to the phase of thefeeding program.

Table 1. Composition of the diet of broilers

\begin{tabular}{lcc}
\hline Calculated composition & Initial phase $(1-28$ days $)$ & Fattening phase $(29-84$ days $)$ \\
\hline EM-Bird Kcal/ kg & 3,100 & 3,200 \\
Crude proteing/ kg & 220.00 & 200.00 \\
Gross fiberg/ kg & 35.20 & 32.70 \\
Mineral matterg/ kg & 53.10 & 50.80 \\
Lysineg / kg & 12.20 & 10.80 \\
Calciumg /kg & 10.00 & 10.00 \\
Total phosphorusg/ kg & 6.80 & 6.60 \\
Available phosphorusg/ kg & 4.80 & 4.80 \\
Sodiumg/kg & 1.70 & 1.70 \\
\hline
\end{tabular}


At 84 days of age two birds each were selected from the average of chicken's weight of the treatment and put under fasting for 12 hours. Was performed the conventional slaughter (stunning, bleeding, plucking and evisceration), and then make up the cuts following the standard procedures of the slaughterhouse.

$$
y=A e^{E \theta(-k t)}+\varepsilon, \text { and Logistics, } y=A\left(1-e^{-k t}\right)^{-m}+\varepsilon,
$$

where $y$ is the weight at age $\mathrm{t}, A$, asymptotic weight when tends to infinity over, that is, this parameter is interpreted as weight in adult age, $B$, an integration constant related to the initial weight of the animal and without a well-defined biological interpretation. The value of $B$ is determined by initial values of $Y$ et, $K$ is interpreted as
For determination of growth curves was used the same methodology of Oliveira et al. (2000), where were used three nonlinear models to see which best described the average growth curve, as follows: Von Bertalanffy, $y=A\left(1-B e^{-K t}\right)^{3}+\varepsilon ;$ Gompertz,

$$
\mathrm{TC}=\operatorname{Pm} \cdot B(\operatorname{Exp}(-\operatorname{Exp}(-b(T t \mathrm{t})))) \cdot(E x p(-b \cdot(t t \mathrm{~s})))
$$

The parameters for the models were estimated by Gauss Newton modified by the NLIN procedure of SAS (SAS Institute, 1999).

Data about zoo technical performance evaluated were the average weight $(\mathrm{kg})$, feed consumption ( $\mathrm{kg} /$ bird), weight gain (grams/bird/day), feed conversion (grams/ grams) and viability (\%) of the birds. The hot carcass weight $(\mathrm{kg})$ was measured immediately after slaughter and carcass yield (\%) calculated the relationship between hot carcass weight eviscerated and weight fasting. The commercial cuts $(\mathrm{kg})$ were breast, drumstick + thigh, back, wing.

The analysis of variance of the evaluated parameters was realized with the aid of statistical analysis program Minitab 14, and compare of means were made using the Tukey test with $\alpha=0.05$. maturation rate, which must be understood as the change in weight relative to the weight at maturity, or as an indicator of the speed with which the animalis approaching of its adult size.

Growth rates (g/day) were calculated by the derivative of the Gompertz equation:

\section{RESULTS AND DISCUSSION}

The estimates of the equations of growth curves showed higher settings with determination coefficients above 0.93 (Table 2), with the Gompertz equation showed a better adjustment, when compared toothers.

The results are similar to studies conducted by Goliomytis et al. (2003) and Norris et al. (2007) who found good adjustment for the growth of lineages to equations of Gompertz, Logistic and Von Bertalanffy still while the analyzes performed by the models Richards and Brody have not converged. The parameters of the growth curve and the growth rate of broilers lineages studied, are presented in Table 3.Master Gris Cou Plumegot greater asymptotic weight and maximum absolute growth rate(AGR maximum), followed of 
Rev. Bras. Saúde Prod. Anim., Salvador, v.16, n.2, p.420-429 abr./jun.., 2015 http://www.rbspa.ufba.br ISSN 15199940

lineages Redbro Cou Nu, Gris Barré Couplume and Gris Barré Cou Nu.

All lines showed high determination coefficient. The inflection point of the growth rate was lower in Master Gris
Cou Plume lineage compared to other lineages, and the lineage Gris Barré Cou Plume got the biggest inflection point. The Redbro Cou $\mathrm{Nu}$ lineage showed the greater weight in inflection.

Table 2. Parameters of growth of broilers raised with access to the paddock curve, according to the models of Gompertz, Logistic and Von Bertalanffy

\begin{tabular}{lccc}
\hline \multirow{2}{*}{ Parameter } & \multicolumn{3}{c}{ Models } \\
\cline { 2 - 4 } & Gompertz & Logístico & Van Bertalanffy \\
\hline A - Asymptotic Weight $(\mathrm{Kg})$ & 3.53 & 2.69 & 4.61 \\
B - Interaction Constant & 4.723 & 31.640 & 0.088 \\
K - Maturity Rate & 0.0302 & 0.0655 & 0.0182 \\
$\mathrm{r}^{2}$ - Coefficient of determination & 0.94 & 0.93 & 0.93 \\
\hline
\end{tabular}

Table 3. Parameters of growth and rate of growth of strains of chickens raised created with access to the paddock set the Gompertz curve model

\begin{tabular}{lcccc}
\hline \multirow{3}{*}{ Parameter } & \multicolumn{4}{c}{ Lineages } \\
\cline { 2 - 5 } & $\begin{array}{c}\text { Redbro Cou } \\
\mathrm{Nu}\end{array}$ & $\begin{array}{c}\text { Gris Barré Cou } \\
\mathrm{Nu}\end{array}$ & $\begin{array}{c}\text { Master Gris Cou } \\
\text { Plume }\end{array}$ & $\begin{array}{c}\text { Gris Barré } \\
\text { Cou Plume }\end{array}$ \\
\hline A - Asymptotic weight $(\mathrm{Kg})$ & 3.694 & 3.277 & 3.7229 & 3.5918 \\
B - Interaction constant & 4.663 & 4.426 & 5.1079 & 4.7453 \\
K - Rate maturity & 0.030 & 0.028 & 0.0345 & 0.0267 \\
$\mathrm{R}^{2}$ - Coefficient of determination & 0.98 & 0.98 & 0.97 & 0.97 \\
Weightat inflection & 1.448 & 1.205 & 1.369 & 1.321 \\
Inflection point & 33.01 & 35.46 & 28.98 & 37.45 \\
Maximum TCA & 0.041 & 0.034 & 0.047 & 0.035 \\
\hline
\end{tabular}

*TCA-maximum absolute growth rate.

Gompertz to body weight, indicate greater mature weights in lineages of rapid growth when compared to slowgrowing lineages. The differences in the parameters of the Gompertz equation suggested that the studied lineages have different growth potential, where the lineage Master Gris Cou Plume grew faster, followed by the Redbro Cou $\mathrm{Nu}$, and even strains Gris Barré Cou Nu and Gris Barré Cou Plume present growth curve similar.

In the literature, there were no reports of the growth of these lineages studied, however observed birds lineage Master Gris Cou Plume are earlier indicating that this lineage is not suitable for alternate farming systems(with access to the paddock), where there is a needlateanimals. According to Blagojević et al. (2009), when the estimated parameters of the Gompertz equation, found greater weight maturity Sasso lineage when compared to birds the ISA Label.

The growth curves and growth rates of the lines studied are presented in Figure 1 and 2 . The lineages studied presented curve overlapped up to 21 days old, 28 days for Master Gris Cou Plume line and 35 for Redbro Cou Nu line. The curves were more upside when 
Rev. Bras. Saúde Prod. Anim., Salvador, v.16, n.2, p.420-429 abr./jun.., 2015 http://www.rbspa.ufba.br ISSN 15199940

compared to lineage Gris Barré Cou Nu and Gris Barré Cou Plume, however, they showed overlapping curves throughout the period analyzed.

Santos et al. (2005) reported that birds intended for production alternative, must be slaughtered with at least 85 days old, and the use of lines with greater growth potential must be accompanied by management practices such as dietary restriction, which modify the growth curve of these birds so that they achieve market weight at age stipulated.

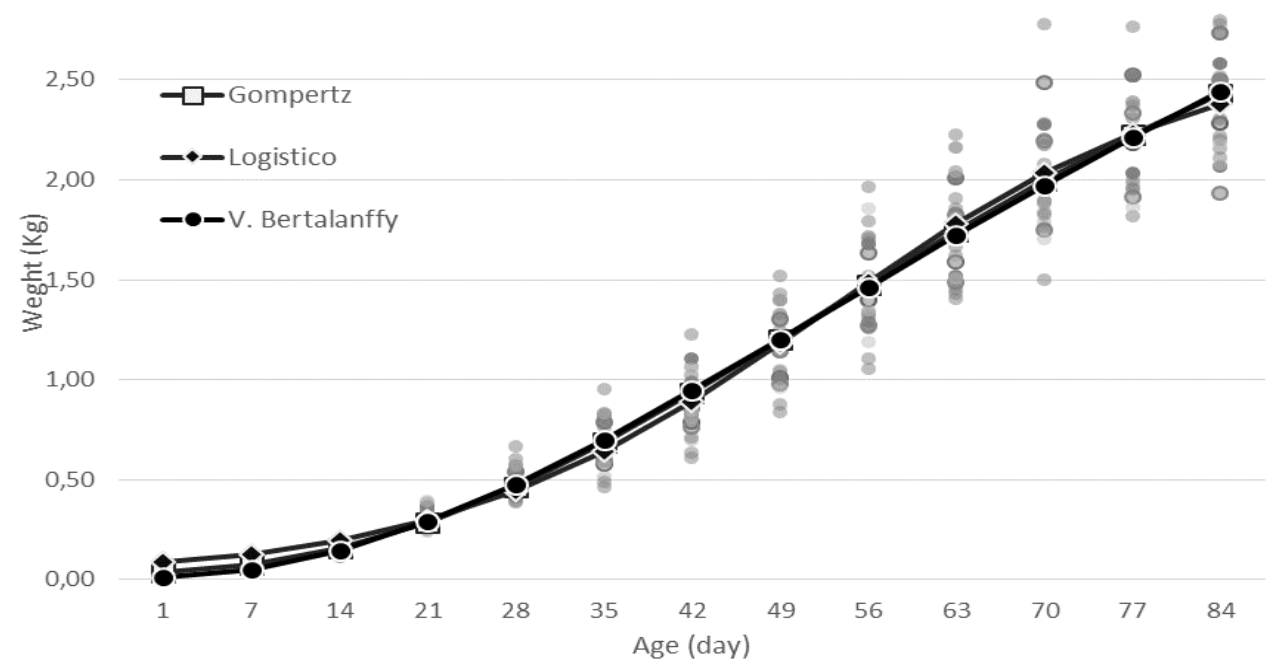

Figure 1. Growth curve of broilers reared in system with access to paddock equations adjusted by Gompertz, Von Bertalanffy and Logistics

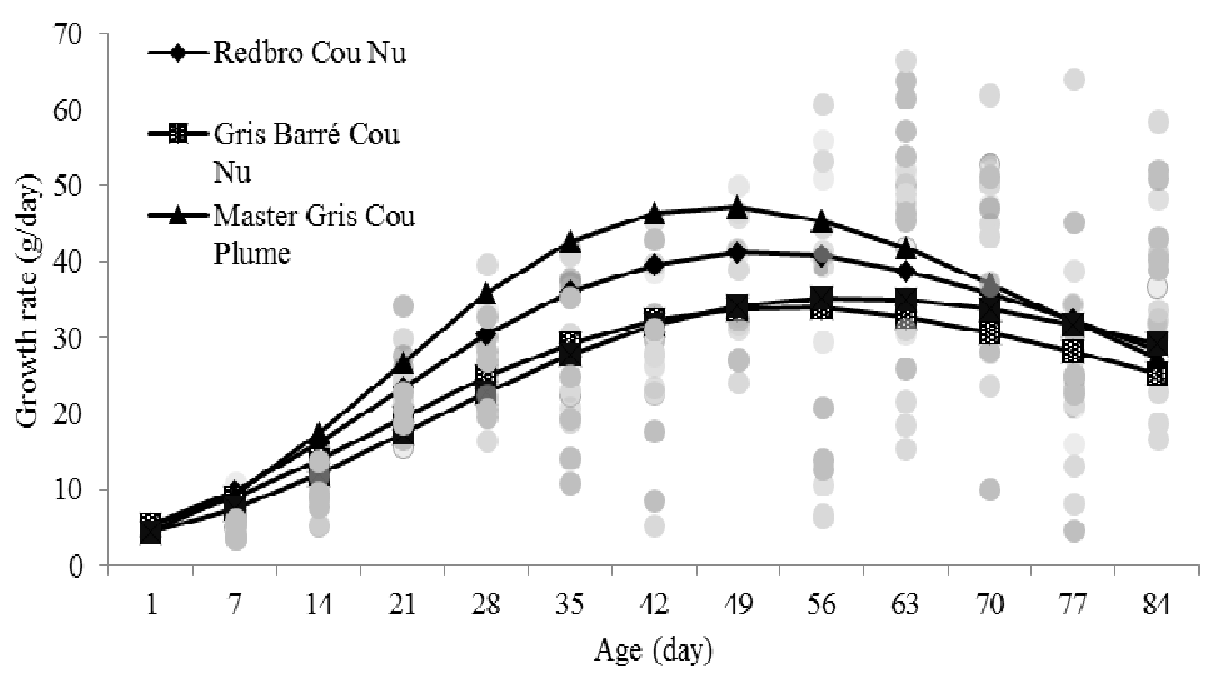

Figure 2. Growth rate of broiler chickens with different growth rates, created in the system with access to paddock adjusted by Gompertz equation 
Rev. Bras. Saúde Prod. Anim., Salvador, v.16, n.2, p.420-429 abr./jun.., 2015 http://www.rbspa.ufba.br ISSN 15199940

The French Red Caipira lineage showed growth curve suitable to the creation systems with access to paddocks for 84 days to provide weight of $2.5 \mathrm{~kg}$, considered the average slaughter weight of these animals. In another research Hellmeister Filho et al. (2003) recommended to Label Rouge lineage meet recommendations for the creation of DIPOA Circular No 007/99, says that the birds "Redneck type" must be created for at least of 85 days.

The performance results at 84 days of creation are shown in Table 4. There were no significant differences among the lineages studied for feed conversion. The lineage Master Gris Cou Plume had the lowest viability, higher average weight and weight gain, when compared to lineage Gris Barré Cou Nu.

Table 4. Mean (standard deviation) of growth performance of strains of broiler chickens raised with access to the paddock( $1-84$ days $)$

\begin{tabular}{|c|c|c|c|}
\hline Lineage & Weight (g) & Feed intake(g/bird) & $\begin{array}{l}\text { Weight gain } \\
\text { (g/bird/day) }\end{array}$ \\
\hline Redbro Cou Nu & $2497.0^{\mathrm{ab}} \pm 15.0$ & $5703.0^{\mathrm{ab}} \pm 34.0$ & $28,71^{\mathrm{ab}} \pm 1,75$ \\
\hline Gris Barré Cou Nu & $2126.0^{\mathrm{b}} \pm 13.0$ & $5151.0^{\mathrm{b}} \pm 26.0$ & $24,35^{\mathrm{b}} \pm 1,52$ \\
\hline Master Gris Cou Plume & $2708.0^{\mathrm{a}} \pm 34.0$ & $6441.0^{\mathrm{a}} \pm 11.3$ & $31,31^{\mathrm{a}} \pm 4,02$ \\
\hline Gris Barré Cou Plume & $2123.0^{\mathrm{ab}} \pm 54.0$ & $5720.0^{\mathrm{ab}} \pm 62.0$ & $24,48^{\mathrm{b}} \pm 6,41$ \\
\hline CV $(\%)$ & 7.20 & 13.42 & 9,54 \\
\hline Value $\mathrm{P}$ & 0.015 & 0.030 & 0,015 \\
\hline & \multicolumn{2}{|c|}{ Feed conversion $(\mathrm{g} / \mathrm{g})$} & $\begin{array}{r}0,015 \\
\text { Viability (\%) }\end{array}$ \\
\hline Redbro Cou Nu & $2.36 \pm 0$ & \multicolumn{2}{|c|}{$85.90^{\mathrm{ab}} \pm 3.14$} \\
\hline Gris Barré Cou Nu & $2.53 \pm 0$ & \multicolumn{2}{|c|}{$96.15^{\mathrm{a}} \pm 6.43$} \\
\hline Master Gris Cou Plume & $2.46 \pm 0$ & \multicolumn{2}{|c|}{$75.64^{b} \pm 16.43$} \\
\hline Gris Barré Cou Plume & $3.08 \pm 1$ & \multicolumn{2}{|c|}{$82.05^{\mathrm{ab}} \pm 10.50$} \\
\hline $\mathrm{CV}(\%)$ & 10.0 & \multicolumn{2}{|c|}{12.23} \\
\hline Value $\mathrm{P}$ & 0.37 & \multicolumn{2}{|c|}{0.020} \\
\hline
\end{tabular}

The growth rate influences on the viability of animals created under alternative systems (with access to paddock) according Quentin et al. (2003) for chickens created under semiconfinement systems, fast growing strains have lower viability when compared to slow-growing lineages. Other results realized by Varoli Junior et al. (2000), indicate a lower viability of Ross birds, compared with ISAS757$\mathrm{N}$ (naked neck and slow growth), at 49 daysof age.

Showed higher carcass weight, chest, thigh + drumstick, back, and wing for Master Gris Cou Plume lineage compared to Gris Barré Cou Nu and Gris Barré Cou Plume (Table5). There were no significant differences in carcass yield among the lineages studied.

The lineage Master Gris Cou Plume showed similar performance with lineage Red Bro Cou Nu and Gris Barré Cou Plume. According to Gonçalves \& Ramos (2010), the birds of lineage Redbro Cou $\mathrm{Nu}$ had a higher average weight gain in relation to a lineage Plume Gris Barré Cou, however similar the birds of lineage Master Gris Cou Plume.

Almeida \& Zuber (2002) report on research evaluating commercial strains (X44N -naked neck, and X44neckcovered), created on a system with access to grazing, the results indicate the superiority of the neck plumed 
Rev. Bras. Saúde Prod. Anim., Salvador, v.16, n.2, p.420-429 abr./jun.., 2015 http://www.rbspa.ufba.br ISSN 15199940

animals in compeer with animals naked neck. In this study there was no predominant effect of the plumage of the neck in the zoo technical performance. For carcass characteristics Thutwa et al. (2012) found no influence of the neck plumage.

Even with the differences in zoo technical performance among the lineages studied, not the significance of differences between means indicates there is a ratio of body weight after fasting and weight of the eviscerated carcass. Different results of Lopez et al. (2011) evaluated when two strains intended commercialization, to creation so hennery, that despite the lineages did not differ in weight, the birds lineage had a significantly higher carcass yield and breast meat yield, thus exemplifying the differences between strains, in terms of income.

Table 5. Yield caracaça and commercial cuts strains of chickens bred with access to paddock

\begin{tabular}{|c|c|c|c|}
\hline Lineages & Carcass eight $(\mathrm{g})$ & Carcass yield (\%) & Chest (g) \\
\hline Redbro Cou Nu & $2037.0^{b} \pm 0.189$ & $77.04 \pm 2.70$ & $508.0^{\mathrm{a}} \pm 0.048$ \\
\hline Gris Barré Cou Nu & $1634.0^{c} \pm 0.106$ & $76.32 \pm 2.03$ & $379.0^{\mathrm{b}} \pm 0.031$ \\
\hline Master Gris Cou Plume & $2253.0^{\mathrm{a}} \pm 0.249$ & $76.69 \pm 2.76$ & $569.0^{\mathrm{a}} \pm 0.083$ \\
\hline Gris Barré Cou Plume & $1735.0^{\mathrm{c}} \pm 0.170$ & $74.88 \pm 2.09$ & $410.0^{\mathrm{b}} \pm 0.047$ \\
\hline CV (\%) & 9.70 & 3.17 & 11.99 \\
\hline \multirow[t]{2}{*}{ Value $\mathrm{P}$} & $>0.001$ & 0.153 & $>0.001$ \\
\hline & Thigh + drumstick $(\mathrm{g})$ & Back $(\mathrm{g})$ & Wing $(g)$ \\
\hline Redbro Cou Nu & $582.0^{\mathrm{ab}} \pm 0.061$ & $441.0^{\mathrm{a}} \pm 0.068$ & $214.0^{\mathrm{ab}} \pm 0.026$ \\
\hline Gris Barré Cou Nu & $478.0^{c} \pm 0.061$ & $352.0^{b} \pm 0.042$ & $178.0^{c} \pm 0.021$ \\
\hline Master Gris Cou Plume & $653.0^{\mathrm{a}} \pm 0.061$ & $489.0^{\mathrm{a}} \pm 0.075$ & $231.0^{\mathrm{a}} \pm 0.029$ \\
\hline Gris Barré Cou Plume & $510.0^{\mathrm{bc}} \pm 0.061$ & $358.0^{\mathrm{b}} \pm 0.044$ & $196.0^{\mathrm{bc}} \pm 0.023$ \\
\hline CV (\%) & 12.35 & 14.50 & 12.22 \\
\hline Value $\mathrm{P}$ & $>0.001$ & $>0.001$ & $>0.001$ \\
\hline
\end{tabular}

The differences among the lineages studied were found on carcass characteristics, where the lines Master Gris Cou Plume and Redbro Cou Nu, showed similar weight sonhischest, thigh + drumstick, wings and back indicating a similarity between these lineages, although no differences between carcass yields of these lineages.

The lineages Redbro Cou $\mathrm{Nu}$ and Master Gris Cou Plume showed similar performance, and the birds of the Redbro Cou $\mathrm{Nu}$ lineages showed growth characteristics more suitable for alternative creations, with access to the paddock area.

\section{ACKNOWLEDGEMENTS}

The Foundation Amazonia Paraense (Fapespa) for financial support, the Municipal Secretariat of Rural Production of Parauapebas, and UFRA - Campus Parauapebas for the availability their infrastructure and logistical support. 
Rev. Bras. Saúde Prod. Anim., Salvador, v.16, n.2, p.420-429 abr./jun.., 2015 http://www.rbspa.ufba.br ISSN 15199940

\section{REFERENCES}

ALMEIDA, A.M.; ZUBER, U. Influência das interações estirpe-sexo e maneio-ração sobre o peso vivo e o rendimento de carcaça em frangos do tipo "campestre". Revista Portuguesa de CiênciasVeterinarias, v.97, p.139142, 2002.

BLAGOJEVIĆ, M.; PAVLOVSKI, Z.; ŠKRBIĆ, Z.; LUKIĆ, M.;

MILOŠEVIĆ, N.; PERIĆ, L.The effect of genotype of broiler chickens on carcass quality in extensive rearing system. ActaVeterinaria, v.59, n.1, p.91-97, 2009.

BOELLING, D.; GROEN, A. F.; SORENSEN, P.; MADSEN, P.; JENSEN, J. Genetic improvement of livestock for organic farming systems. Livestock Production Science, v.80, p.79-88, 2003.

BRASIL. Ministério da Agricultura, Pecuária e Abastecimento. Ofício Circular DOI/DIPOA No 007/99, de 19 de maio de 1999. Normatização e comercialização do frango Caipira ou frango Colonial, também denominado "Frango Tipo ou Estilo Caipira" ou “Tipo ou Estilo Colonial”. Diário Oficial da República Federativa do Brasil, DF, 1999.

FARMER, L.J.; PERRY, G.C.; LEWIS, P.D.; NUTE, G.R.; PIGGOTT, J.R.; PATTERSON, R.L.S. Responses of two genotypes of chicken to the diets and stocking densities of conventional uk and label rouge production systems-ii. Sensory attributes. Meat Science, v.47, p.77-93, 1997.

GALVÃO, E.U.P.; MENEZES, A.J.E.A.; VILAR, R.R.L.; SANTOS, A.A.R. dos. Análise da renda e da mão- de-obra nas unidades agrícolas familiares da comunidade de nova colônia, município de Capitão Poço, Pará. Amazônia: Ciência \& Desenvolvimento, v.1, p.35-45, 2005.

GOLIOMYTIS, M.; PANOPOULOU, E.; ROGDAKIS, E. Growth curves for body weight and major component parts, feed consumption, and mortality of male broiler chickens raised to maturity. Poultry Science, v.82, p.1061-1068, 2003.

GONÇALVES, J.B.S.; RAMOS, C. da R. Avaliação de linhagens de aves de corte tipo caipira submetidas ao bioclima do litoral do Paraná. Revista Scientia Rural, p.49-63, 2010.

GOMES, I. Sustentabilidade social e ambiental na agricultura familiar. Revista de Biologia e Ciências da Terra, v.5, n.1, p.1-17, 2004

HELLMEISTER FILHO, P.; MENTEN, J.F.M.; SILVA, M.A.N.; COELHO, A.A.D.; SAVINO, V.J. M. Efeito de genótipo e do sistema de criação sobre o desempenho de frangos tipo caipira. Revista Brasileira de Zootecnia, v.32, p.1883-1889, 2003.

LEWIS, P.D.; PERRY, G.C.; FARME, L.J.; PATTERSON, R.L.S. Responses of two genotypes of chicken to the diets and stocking densities typical of uk and 'label rouge' production systems: I. Performance, behaviour and carcass composition. Meat Science, v.45, p.516, 1997.

LÓPEZ, K.P.; SCHILLING, M.W.; CORZO, A. Broiler genetic strain and sex effects on meat characteristics. Poultry Science, v.90, p.1105-1111, 2011. 
Rev. Bras. Saúde Prod. Anim., Salvador, v.16, n.2, p.420-429 abr./jun.., 2015 http://www.rbspa.ufba.br ISSN 15199940

NARINC, E.; AKSOY, T.;

KARAMAN, E.; ILASLAN CUREK, D. Analysis of fitting growth models in medium growing chicken raised indoor system. Trends in Animal and Veterinary Sciences, v.1, p.12-18, 2010.

NAZARENO, A.C.; PANDORFI, H.; ALMEIDA, G.L.P.; GIONGO, P.R.; PEDROSA, E.M.R.; GUISELINI, C. Avaliação do conforto térmico e desempenho de frangos de corte sob regime de criação diferenciado. Revista Brasileira de Engenharia Agrícola e Ambiental, v.13, p.802-808, 2009.

NORRIS, D.; NGAMBI, J.W.; BENYI, K.M. Analysisofgrowth curves ofindigenous male vend and naked neck chickens. South African Journal of Animal Science, v.37, p.21-26, 2007.

OLIVEIRA, H.N.L; LÔBO, R.B.; PEREIRA, C.S. Comparação demodelos não-lineares para descrever o crescimento de fêmeasda raça Guzerá. Pesquisa Agropecuária Brasileira, v.35, n.9, p.1843-1851, 2000.

QUENTIN, M.; BOUVAREL, I.; BERRI, C.; BIHAN-DUVAL, E.L.; BAEZA, E.; JEGO,Y.; PICARD, M. Growth, carcass composition and meat quality response to dietary concentrations in fast, medium and slow-growing commercial broilers. Animal Research, v.52, p.65-77, 2003.

SANTOS, A.L.; SAKOMURA, N.K.; FREITAS, E.R.; FORTES, C.M.L.S.; CARRILHO, E.N.V.M.; FERNANDES, J.B.K. Estudo do crescimento, desempenho, rendimento de carcaça e qualidade de carne de três linhagens de frango de corte. Revista Brasileira de Zootecnia, v.34, p.1589-1598, 2005.
SAS Institute. User's guide: statistics. 6.ed. Cary, 1999. v.3, 373p.

THUTWA, K.; NSOSO, S.J.; KGWATALALA, P.M.; MOREKI, J.C. Comparative live weight, growth performance, feed intake, carcass traits and meat quality in two strains of tswana chickens raised under intensive system in south east district of botswana. International Journal of Applied Poultry Research, v. 1, p. 2126, 2012.

VAROLI JÚNIOR, J.C.; GONZÁLES, E.R.; ROÇA, D.E.; MENDES,A. A.; MORCELI,L.Desempenho e qualidade de carcaça de frangos com pescoço pelado. ARS Veterinária, v.16, n.3, p.122-129, 2000.

Data de recebimento: $24 / 05 / 2014$

Data de aprovação: 27/03/2015 